Check for updates

Montreal, Canada

Cite this as: BMJ 2021;374:n2050 http://dx.doi.org/10.1136/bmi.n2050 Published: 18 August 2021

\title{
Covid-19: Australian outbreak surges as New Zealand sees first domestic cases in six months
}

\section{Owen Dyer}

New Zealand and much of eastern Australia are in lockdown this week, but these two countries that once shared a covid bubble are on divergent trajectories as New Zealand scrambles to maintain a "zero covid" strategy that Australia has been forced to abandon.

The measures imposed in Auckland and in Sydney are similar in scope but very different in their genesis and likely duration. Sydney's state, New South Wales, has been in lockdown for eight weeks, but an ever tightening patchwork of local restrictions has failed to stop hundreds of new cases of the delta variant appearing each day.

On 17 August New Zealand imposed a snap three day lockdown-seven days in Auckland-after detecting one case, the country's first domestic transmission in six months.

New South Wales, the epicentre of Australia's outbreak, reported a record 633 locally acquired cases on 18 August. The national figure reached 677 new cases-a number exceeded only by the two worst days of Australia's second wave 12 months ago.

"I can't express enough my level of concern at these rising numbers," said New South Wales's chief health officer, Kerry Chant. "Every person is passing on the virus to more than one person."

The new cases remain heavily concentrated in southwestern suburbs of Sydney, but a new outbreak is hitting inland indigenous communities around Dubbo. Most Australian states have partly closed their borders.

\section{Stamping it out}

In New Zealand, meanwhile, the first full day of the snap lockdown brought news of 10 new cases. One of the infected people is a teacher, another a fully vaccinated nurse. The cases were linked by genomic sequencing to the Sydney outbreak, but how the contagion penetrated New Zealand is not clear.

The country's new lockdown was triggered by an unexplained infection in a 58 year old Auckland man, which has since been confirmed as New Zealand's first domestic case of the delta variant. He was seeking a vaccine appointment when he developed symptoms. His age group of 55-6o became eligible for the shot only on 6 August.

The man travelled to Coromandel while unknowingly infectious, prompting a national level 4 lockdown, the strictest category. The 10 new cases, who are contacts of his, are mostly young people who have been socially active in recent days, warned the prime minister, Jacinda Ardern, as she predicted more cases.
"Complying with these [lockdown] rules, making sure we do all we can to stamp it out, still remains the best strategy in the world right now," she told Radio New Zealand on 18 August, noting that some highly vaccinated countries were struggling with the delta variant. "These measures have worked before, and they will work again."

Like many Pacific countries that have relied on strong border controls, Australia and New Zealand still have low vaccine coverage. New Zealand's full vaccination rate, at $17.3 \%$, is the lowest among the Organisation for Economic Co-operation and Development nations and below the worldwide rate of $23.7 \%$.

In Australia $22.5 \%$ of people are fully vaccinated, but uptake has risen sharply in recent days.

\section{Waiting for Pfizer}

Australia's vaccine strategy was originally based on the AstraZeneca vaccine, but many Australians adopted a "waiting for Pfizer" policy amid mixed government messages regarding blood clot risk and comments from the federal health minister in May promising mRNA vaccines later in the year. ${ }^{1}$ The government initially recommended the AstraZeneca shot only in people over 6o, but as cases surged it advised all adults "who do not have immediate access to the Pfizer vaccine" to have AstraZeneca instead. ${ }^{2}$

Australia expects to receive 10 million doses of Moderna's mRNA vaccine later this year and has just made an emergency purchase of one million Pfizer doses from Poland, whose own vaccination programme has slowed amid widespread hesitancy. Half of these doses will be administered in the coming days to 16-39 year olds in Sydney.

Australia has approved Pfizer's vaccine for at-risk children aged 12 and over. Victoria, the second hardest hit state, reported on 18 August that its outbreak was disproportionately striking young people. Of 246 active cases in Victoria, 56 are under 9 years old and 55 are aged 10-19.

In Sydney the New South Wales premier, Gladys Berejiklian, warned that even hitting the government's target of $80 \%$ vaccine coverage would not allow the region to end its lockdown unless new cases fell below 40 a day.

"The extent of your freedom depends on case numbers," she said, citing the Doherty Institute report that guides Australia's covid policy. ${ }^{3}$

New Zealand, which has seen only 26 covid deaths in the pandemic, suspended its bubble arrangement with Australia on 22 July, and Ardern has ruled out reopening it this year. Justifying her own government's swift lockdown, she referenced 
Australia, explaining, "We've seen the dire consequences of taking too long to act in other countries, not least our neighbours.”

1 Tsirtsakis A. "It's a dangerous strategy for people to hold off": GPs urge eligible patients to get vaccinated now. News GP2021 May 20. https://www1.racgp.org.au/newsgp/clinical/it-s-a-dangerous-strategy-for-people-to-hold-off-g

2 Australian Government Department of Health. ATAGI statement on use of covid-19 vaccines in an outbreak setting. 13 Jul 2021. https://www.health.gov.au/news/atagi-statement-on-use-ofcovid-19-vaccines-in-an-outbreak-setting

3 Doherty Institute. Doherty modelling report revised 10th August 2021. Aug 2021.

https://www.doherty.edu.au/uploads/content_doc/DohertyModelling_NationalPlan_and_Addendum_20210810.pdf

This article is made freely available for use in accordance with BMJ's website terms and conditions for the duration of the covid-19 pandemic or until otherwise determined by BMJ. You may use, download and print the article for any lawful, non-commercial purpose (including text and data mining) provided that all copyright notices and trade marks are retained. 